\title{
Study On the By Catch Loss in Two Coastal Districts of West Bengal, India
}

\author{
Chattopadhyay NR* \\ Department of Zoology , Rajiv Gandhi University , Rono Hills , Doimukh , Itanagar 791112 , Arunachal Pradesh , India
}

Received:September 12, 2017; Accepted: September 25, 2017; Published: October 26, 2017

*Corresponding author: Chattopadhyay NR, Department of Zoology, Rajiv Gandhi University , Rono Hills , Doimukh , Itanagar 791112 , Arunachal Pradesh , India E-mail: nrchatterjee40@gmail.com

\begin{abstract}
By catch is now a worldwide concern among Scientists, policy makers and other discrete bodies concerned with aquatic biodiversity. The term by catch means the incidental catch (retained catch) of nontarget species plus discarded catch, while 'discards' or 'discarded catch' denotes the portion of the catch returned to sea. The problem of discarding and by catch has attracted substantial attention among researchers in the last three decades due to their deleterious effects on marine biodiversity with particular reference to egg bearing adult and young ones of commercially valuable and endangered species. In West Bengal, India two coastal districts, Namkhana and Digha are famous for production of a huge amount by catch and discards in the range of $3000-8500 \mathrm{~kg} /$ month depending on the season. Constituent groups include Bhola, Clupidae, catfish, flat fish, ribbon fish and Carangidae and a number of important groups of fishes. Trawl net is the major contributors of by catch, particularly during shrimp harvest, when discard/ catch ration ranged somewhat from 3:1 to 15:1. Considering the importance this study was initiated covering period of nine month, for documentation of the groups and species caught unintentionally during the capture of target species in two coastal districts of West Bengal, India. A comparative data was created to assess the by catch / discards in terms of weight, percentage, groups and also in terms of seasons and region. The study revealed that large groups important fishes are caught ( 6 or even more) in targeting one or two species.
\end{abstract}

Key words: by catch; discards; trawl net; shrimp harvest; mesh size;

\section{Introduction}

The study was undertaken with a view to inventories the comparable by catch data from two important landing centre of West Bengal, India. Bulk of the marine catches from the Bay of Bengal are routed through two coastal zones ie Namkhana in South 24 Pargona and Dgha in Midnapore district of West Bengal. In both areas the practice of hauling penaeus seed by hand operated net was in vogue form ancient times. Gradually , in the course of time, various indigenous gears like Sarni jal, Drag net, Shoot net, Barrier net has come up and are in use in both the areas, included under the category of traditional non mechanized gears. Though traditional but individual gear differs from each other in their mode of operation, target species and also in the composition of by catch and discards .The available data from both the areas were compared in regard to the yield, in terms of by catch and discards. Results indicate compared to Digha, by catch production was more in Nmakhana. Besides available data are compared in terms of month, season and group wise yield of by catch and discards of the two study areas. This indicate though total catch is more in Digha, by catch is more in Namkhana while discards are more in Digha. A correlation value, in accordance with the months of two regions, when compared, found significant $(\mathrm{P}>0.01$ ) in terms of by catch. Unorganized and unlawful fishing is the practice of two sites without any care for ecosystem or biodiversity of the Bay. Along with this illiteracy, ignorancy and sustenancy led them adopt any means to carry out their target. The poor coastal fisher flock, without being appraised of the incomparable loss on their part, inadvertently involved in activities which are not only negative but will put a threat to their life one day. Besides taking decision, formulation of new laws, creation of new bodies, expressing concern over biodiversity and marine ecosystem, the primary actors should be apprised of the loss on their part.

\section{Materials and methods}

The methodologies used to assess by-catches includes identification of separate catching system, exploration of multiple information system for estimating volume and comparison of discards as we know the success of such study is dependent on accurate identification of diverse pattern of activities, for an example: Length of voyage, Size of vessel, Location of fishing ground, Types of gears, Days of fishing as well as Composition of species and Quantity of species. Initially 4 sampling sites of districts have been selected as mentioned below --

A. South 24-Parganas which includes Namkhana $\left(21.7667^{\circ} \mathrm{N}\right.$, $\left.88.2333^{\circ} \mathrm{E}\right)$ and Diamond harbor $\left(22.2000^{\circ} \mathrm{N}, 88.2000^{\circ} \mathrm{E}\right)$.

B. East Midnapure which includes Digha $\left(21.6800^{\circ} \mathrm{N}, 87.5500^{\circ}\right.$ E) and Sankarpur $\left(21.6344^{\circ} \mathrm{N}, 87.5698^{\circ} \mathrm{E}\right)$. 


\section{Procedure adopted for study}

\section{Selection of Coastal zone}

Two coastal Districts of West Bengal, India, were selected, as mentioned based on the following criteria's as the density of diverse kind of net operations, the production of landing centre and random application of different kinds of traditional gear

\section{Collection of Samples}

Sampling was conducted fortnightly at each sampling point using different fishing gears

\section{Analysis of samples}

The collected samples were cleaned, segregated, stored \& segregated; the specimens were identified up to species level using standard procedure.

\section{Different sources of by-catch}

By catch is the product of unintentional catch both by mechanized and indigenous non - mechanized gears (Fishing gear type, 2011). In the study area non - mechanized ones includes different gears of indigenous variety as mentioned in (figure 1). Mechanical fishing are mainly done by trawl net .According to fishing methods by catch can further be divided into commercial and traditional fishing as depicted in (figure 2).

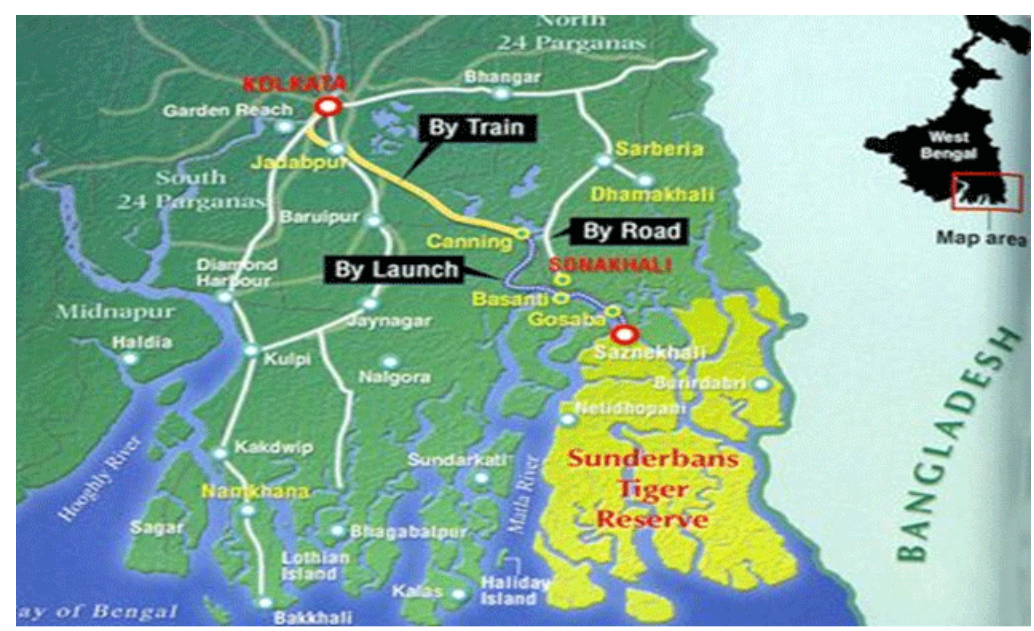

Figure 1: Study area in the coastal part of Namkhana, south 24 Porgonas, and West Bengal, India

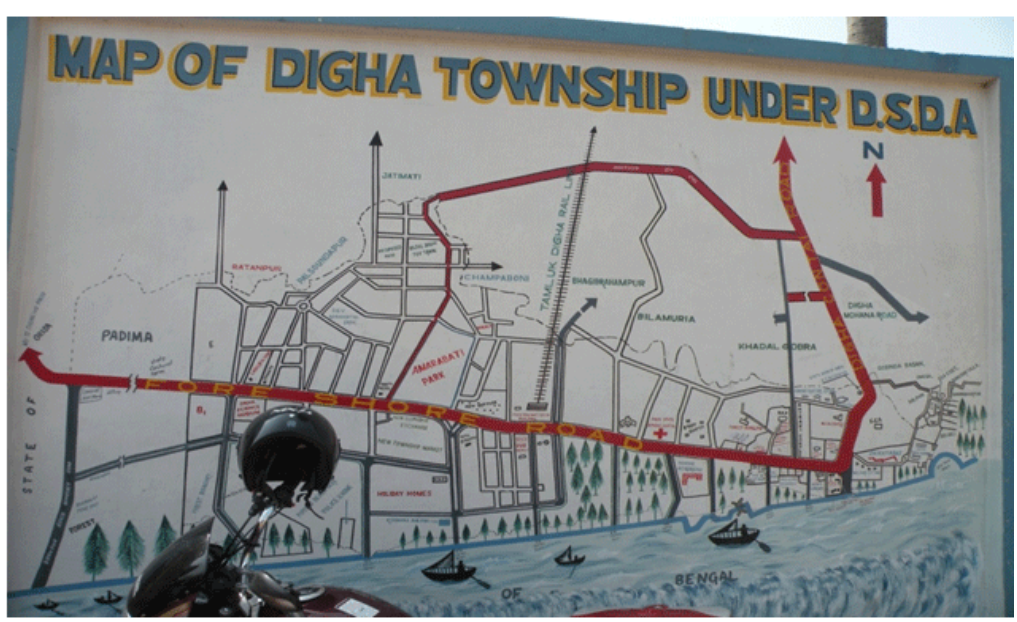

Figure 2: Study area in the coastal districts of Digha and Sankarpur, 24 Pargonas (North), West Bengal, India

Gears used during traditional fishing and the related by catch

\section{Sarni jal}

These are long (200 - $250 \mathrm{~m})$ narrow meshed (5-10mm) nylon net generally used to capture mainly Secutor sp.(gang chanda), Esculosa thoracata (gang morala) \& along with by-catch species which includes crabs (Portunas sanguinolentus, Charibdis cruciata, P. pelagicus), Octopus (Octopus dollfusi), Loligo (Loligo duvaucelii), Para mach (Scomberoides lysan), Parse (Mugil parcia, Liza tade, Mugil cephakus), Puffer fish, Tricanthus sp., Jelly fish etc. species (Table 2). For operation, head ropes and bottom lines 


\begin{tabular}{|c|c|c|}
\hline Area & $\begin{array}{c}\text { Estimated By-catch } \\
\text { (mt.) }\end{array}$ & $\begin{array}{c}\text { Estimated Discard } \\
\text { (mt.) }\end{array}$ \\
\hline Northwest Atlantic & 81,665 & 80,031 \\
\hline Northeast Atlantic & 210,297 & 206,091 \\
\hline $\begin{array}{l}\text { West Central } \\
\text { Atlantic }\end{array}$ & $1,310,653$ & $1,271,334$ \\
\hline East Central Atlantic & 123,636 & 61,818 \\
\hline $\begin{array}{l}\text { Mediterranean/ } \\
\text { Black Sea }\end{array}$ & 257,859 & 250,124 \\
\hline Southwest Atlantic & 253,446 & 245,842 \\
\hline Southeast Atlantic & 39,143 & 19,571 \\
\hline $\begin{array}{l}\text { Western Indian } \\
\text { Ocean }\end{array}$ & $1,871,075$ & 748,430 \\
\hline $\begin{array}{l}\text { Eastern Indian } \\
\text { Ocean }\end{array}$ & 482,879 & 289,727 \\
\hline Northwest Pacific & $4,284,408$ & $4,155,903$ \\
\hline Northeast Pacific & 28,269 & 27,421 \\
\hline West Central Pacific & $1,450,352$ & $1,377,835$ \\
\hline East Central Pacific & 590,955 & 561,416 \\
\hline Southwest Pacific & 19,446 & 18,863 \\
\hline Southeast Pacific & 203,677 & 197,567 \\
\hline Total & $11,207,761$ & $9,511,973$ \\
\hline
\end{tabular}

are tied to bamboo pole and the entire operation which lasted for 5 - 6 hrs involves 50-60 manpower in the inshore water during high tide. This net is operated 2-3 times / day except rainy seasons with an average catch of 80-100 kg per haul.

\section{Shoot net (behundi jal)}

The commonest gear for collection of $P$. monodon PL in West Bengal is the Medinipur type of shootnet (Basu \& Pakrasi, 1979). This is a long, funnel-shaped bag net set against the tidal current to filter seed from estuarine water. The size of the net is highly variable and there are various modifications, depending on the nature' of terrain and areas to be covered. The material used for the net is nylon monofilament of $1 \mathrm{~mm}$ mesh. The gamcha (coarse cloth), which is used to collect carp fry, is no more used. The general specifications of the net are: Width- $40 \mathrm{~m}-60 \mathrm{~m}$, Length$50 \mathrm{~m}-75 \mathrm{~m}$ and Height- $13 \mathrm{~m}$, with a tapering end $3 \mathrm{~m}$ in diameter. Shrimp fry-collectors make a knot at the tail end of the shoot net. The contents from the tail end are periodically emptied into an aluminum utensil by untying the knot.

\section{Shoot net operation from shore}

This simple method requires minimum manpower. At the beginning of high tide, a long bamboo is placed horizontally across the river by fixing one end to the shore while the other end projects over the water. The shoot net is placed against the current and is kept in position by means of a long nylon rope, one end of which is tied to the free end of the bamboo pole, while the other is tied to a small bamboo pin driven into the shore. The catches are emptied periodically (generally every $1 / 2$ hour), depending on the catch rate. Two persons are required to handle such a net. The nets are operated in waist-to-chest-deep water. With the rise of the water level, the horizontal bamboo is adjusted and the net is soaked for further collections. This process is repeated till the tidal current becomes feeble and collections are no longer possible. Fixing the shoot net in reverse direction, fry can be collected during ebb tide, when the velocity of the water is sufficient to keep the net in position. This type of net operation is common at Harwood Point and a series of shoot nets arc operated all along the shore line for collection of $P$. monodon fry.

\section{Shootnet operation from boats}

Collection of post-larvae is also done in mid-stream using the same conical, behundi-type shoot net from a boat. Before onset of high tide, the boat is taken to midstream and anchored. Two or three shoot nets are tied to the boat using nylon ropes. As soon as high tide starts and the water current is sufficiently strong, the nets are placed in position side by side. The net mouths are kept wide apart and fully stretched. When there is good catch, the nets are lifted at intervals of 30 minutes and the contents emptied. No adjustment of the nets is necessary; attached as they are to the drifting boat; they automatically adjust to the rise or fall in water level. This type of collection is common in the open water of the Namkhana, Kakdwip and Digha region.

Species captured by shoot net are given in (Table 3). 


\begin{tabular}{|c|c|c|c|c|}
\hline Species & Gear & Target species & By-catch & Discarded species \\
\hline \multirow{3}{*}{\multicolumn{2}{|c|}{$\begin{array}{l}\text { larvae(meen), Metapenaeus } \\
\text { monocerus(baouta), } \\
\text { M. dobsoni(brown), } P . \\
\text { indicus(kori) }\end{array}$}} & \multirow{27}{*}{$\begin{array}{l}\text { Penaeus monodon larvae } \\
\text { (Meen) }\end{array}$} & \multirow{27}{*}{$\begin{array}{c}\text { Except larvae } \text { P. monodon all } \\
\text { fin fish shell fishes are by } \\
\text { catch }\end{array}$} & \multirow{27}{*}{$\begin{array}{c}\text { Except larvae } P \text {. monodon } \\
\text { all fin fish shell fishes are } \\
\text { discarded }\end{array}$} \\
\hline & & & & \\
\hline & & & & \\
\hline \multicolumn{2}{|l|}{ Crabs larvae } & & & \\
\hline \multicolumn{2}{|l|}{ Larvae of Shilago shiama } & & & \\
\hline \multicolumn{2}{|l|}{ Larvae of Mullets } & & & \\
\hline \multicolumn{2}{|l|}{ 1. Mugil parcia } & & & \\
\hline \multicolumn{2}{|l|}{ 2. Lliza tade } & & & \\
\hline \multicolumn{2}{|l|}{ 3. Mugil cephalus } & & & \\
\hline \multicolumn{2}{|l|}{ Larvae of Croakers } & & & \\
\hline \multicolumn{2}{|l|}{ 1. Johoni gangeticus } & & & \\
\hline \multicolumn{2}{|l|}{ 2. Johoneops sena } & & & \\
\hline \multirow{2}{*}{\multicolumn{2}{|c|}{$\begin{array}{l}\text { 3. Otilithoides } \\
\text { biauritius }\end{array}$}} & & & \\
\hline & & & & \\
\hline \multicolumn{2}{|l|}{ 4. O. cuvier } & & & \\
\hline \multicolumn{2}{|l|}{ 5. O. ruber } & & & \\
\hline \multicolumn{2}{|l|}{ 6. Johnius dussumieri } & & & \\
\hline \multicolumn{2}{|l|}{ Larvae of flat fishes } & & & \\
\hline \multicolumn{2}{|l|}{ 1. Cynoglosious } & & & \\
\hline macrolepidopus & & & & \\
\hline \multicolumn{2}{|l|}{ 2. paraplagusia } & & & \\
\hline \multicolumn{2}{|l|}{ bilineata } & & & \\
\hline \multicolumn{2}{|l|}{ 3. Psettodes erumei } & & & \\
\hline Larvae of pomfrets & & & & \\
\hline 1. Pampus argentius & & & & \\
\hline 2. Pampus chinensis & & & & \\
\hline $\begin{array}{l}\text { 3. Parastromateus } \\
\text { niger }\end{array}$ & & & & \\
\hline
\end{tabular}

\section{Barrier nets}

These are very long (100-300 m long and 2.0 - $3.0 \mathrm{~m}$ wide), narrow-meshed (3-5 mm) nylon nets used to trap mullet juveniles which enter into the inshore area and the mangrove-covered tidal mudflats during spring tides. The net, which remains in lowered position during the low tide, is raised during the turn of the tide with the help of strong bamboo poles. Various shellfish and finfish juveniles get trapped in the net as by-catch as the tide recedes (Table 4). Although this gear is quite effective in collecting the juvenile shrimp, large quantities of fish and shrimp fry which are not immediately collected get killed.

\begin{tabular}{|c|c|c|c|c|}
\hline Species & Gear & Target species & By-catch & Discarded species \\
\hline $\begin{array}{ll}\text { 1. } & \text { Juvenile Mugil cephalus } \\
\text { 2. } & \text { Cynoglosious macrolepidopus } \\
\text { 3. } & \text { Paraplagusia bilineata } \\
\text { 4. } & \text { Psettodes erumei } \\
\text { 5. } & \text { Metapenaeus monocerus (baouta) } \\
6 . & \text { M. dobsoni (brown) } \\
\text { 7. } & \text { Penaeus monodon (tiger shrimp) } \\
\text { 8. } & \text { P. indicus (kori) } \\
\text { 9. } & \text { Solensera sp. (bolder) } \\
\text { 10. } & \text { P.semisulcatus (harina or matka) } \\
\text { 11. } & \text { Gamoplites scaber }\end{array}$ & Barrier net/ bedha jaal & $\begin{array}{l}\text { Juvenile Mugil } \\
\text { cephalus }\end{array}$ & $\begin{array}{l}\text { Except Mugil cephalus } \\
\text { all species are by-catch }\end{array}$ & $\begin{array}{c}\text { Except Mugil } \\
\text { cephalus all species } \\
\text { are discarded }\end{array}$ \\
\hline
\end{tabular}




\section{Shrimp by catch thoroughly traditional non- mechanized fishing method}

P. penicillatus, M. brevicornis, M. ensis, P. Indicus, Acetes sp., Exopalaemon styliferus, Palaemon sp., Macrobrachium rude, Varuna litterata, Crabs as Scylla serrata, Portunus Pelagicas, Stolephorus sp.and Liza parsia, Liza tade, Mugil spp., Rhinomugil corsula, Pomfrets as Pampus argenteus, P. Chinensis, Parastromateus niger, Flat fish: Pseudorhombus sp, Lutjanus spp., L. johni and another unidentified species were recorded in this genus, Scatophagus argus, Sciaenids, Trvelly, Gobioides rubicundus This commercially important species, referred to as gulay maach in Bengali is available almost throughout the year.

\section{Trawl net (Trawl of 16-19 $\mathrm{m}$. overall length) and related by catch}

Information obtain from interviews with crew of $16-19 \mathrm{~m}$ length suggested that their discards per vessel per day were a volume comparable to those of the larger trawler. These trawlers pull 3 nets according to size of the species. The length of trawl net is divided into three categories:

$1.120 \mathrm{ft}$. trawl net: this used for catching small fish. Head rope and cod end mesh size $14 \mathrm{~cm}$. and $5 \mathrm{~cm}$. respectively.

$2.130 \mathrm{ft}$. trawl net: this is also used for catching small fish. Head rope and cod end mesh size $32 \mathrm{~cm}$. and $4 \mathrm{~cm}$. respectively.

$3.740 \mathrm{ft}$. trawl net: This is used for catching big fish. Head rope and cod end mesh size $50 \mathrm{~cm}$. and $4 \mathrm{~cm}$. respectively.

Most of the trawler cannot stay at sea as long or retain as much fish because of their dependence on ice. Fisherman when interviewed gave estimate of $80-150 \mathrm{~kg}$ fish catch per haul. Though the production is varying with season to season it appears that relatively small quantities of by-catch are discarded at sea though it is difficult to ascertain the extent and scale of this kind of transaction.

The information available on the species and size distribution of the discarded by-catch is general rather than specific, but nonetheless gives some indication of its value were it to be landed. The main selection criterion in retaining or discarding fish seems to be size, but the cut-off point is different for each type of trawler. Most of the 16-19 m trawlers seem to have a policy of retaining large quantity fish throughout the voyage. The rest of the catch is discarded. Some trawlers will retain more of the catch in the last few days of the voyage; some will not retain any catch until the end of the voyage. The mesh size (stretched) used by these trawlers is supposed to be $30-40 \mathrm{~mm}$ at cod end. Smaller meshes are used by some trawlers.

The most abundant species caught during October to March 2010, were: Sciaenidae (croakers or jewfish), Leiognathidae (silverbellies/ponyfish), Nemipteridae (threadfin bream), Clupeidae (sardines, shads), Trichiuridae (ribbonfish), Carangidae (jacks, travallys), Mullidae (goatfish), Harpadontidae (Bombay duck), Stromatidae, Flat fish, Loligo, Sepia, Shrimp (Table 5).

Everything less than $5 \mathrm{~cm}$ was discarded (20-30 per cent of the by-catch). It is also reported that, surprisingly large Percentage of discarded shrimp of unspecified quality. This indicated that 3040 per cent of the discarded weight may be fin fish. The remaining part of discard is shrimp, small crab, small loligo and sepia. The discarded shrimp species as follows: Metapenaeus affinis, $M$. dobsoni, M. brevicornis, Parapenaeopsis hardwickii and P. stylifera.

\section{Retained fish in order of abundance}

Sciaenidae (croakers or jewfish), Ariidae (catfish), Stromateidae (pomfret) including Black pomfret, Lutjanidae (snapper), Polynemidae (threadfins or tasselfish), Chirocentridae (wolf herring), Muraenesocidae (eel), Synodontidae (lizardfish), Carangidae (queenfish), Scombridae (seerfish, mackerel)

The species distribution of the by-catch varies through the year and with depth and location of trawl. It is observed that the small croakers, threadfin breams, hair tails, pony fish, Lizardfish, shads, sharks and rays as the most abundant by catch species in the sampled area during the study period (October to March). It is also observed that landings of small cuttlefish and flat fish as by-catch. Fisher men in West Bengal discards from these trawlers reported that Jew fish (Scaeanidae) was the most abundant fish percentage, but catfish percentage was also significant.

\section{Size and species composition of fish}

A better understanding of the size distribution of fish in the by-catch is very important, both for considering potential utilization, and for estimating the possible effects of this harvest on fish stocks. Samples of fish that would have been discarded by trawlers are now being collected due to demand of the fish in market. In interviews, the stretched mesh size used was reported by crew to be $30-40 \mathrm{~mm}$ at cod end. The species distribution is probably similar to the catch of the larger trawlers. These trawlers do attempt to land as much fish as possible (much of it salted or dried), subject to space constraints. The stretched mesh size (cod end) used by these trawlers is $30-40 \mathrm{~mm}$. Small fish caught in this trawl is sold for less than Rs $5 / \mathrm{kg}$ in the sampled region much of it is sold at Rs $5 / \mathrm{kg}$ for use as fishmeal.

The procedure followed for discarding by-catch, as recorded during study, is general rather than specific. Though main selection criteria for discarding catch seems to be size, but the cutoff point is different for each type of trawler. Most of the trawlers seem to follow a common policy of retaining large quantity fish throughout the voyage by discarding a small quantity, while some prefer to retain most of the catch for the last few days of the voyage without any discrimination. Again, there are others who do not retain any by-catch until the end of the voyage. The mesh size (Stretched) used are as follows ---

For small fish: Length of the net $120 \mathrm{ft}$. Upper mesh size to Cod end: $14 \mathrm{~cm}, 12 \mathrm{~cm}, 8 \mathrm{~cm}, 6 \mathrm{~cm}, 4 \mathrm{~cm}, 3 \mathrm{~cm}$

For the large fish: Upper mesh size to Cod end: $50 \mathrm{~cm}, 40 \mathrm{~cm}, 32$ $\mathrm{cm}, 26 \mathrm{~cm}, 20 \mathrm{~cm}, 16 \mathrm{~cm}, 12 \mathrm{~cm}, 8 \mathrm{~cm}, 6 \mathrm{~cm}, 4 \mathrm{~cm}$

Commercial fishing affects not only the species targeted, but also several other species that are caught incidentally. This is commonly referred to as by catch. By catch generally include 


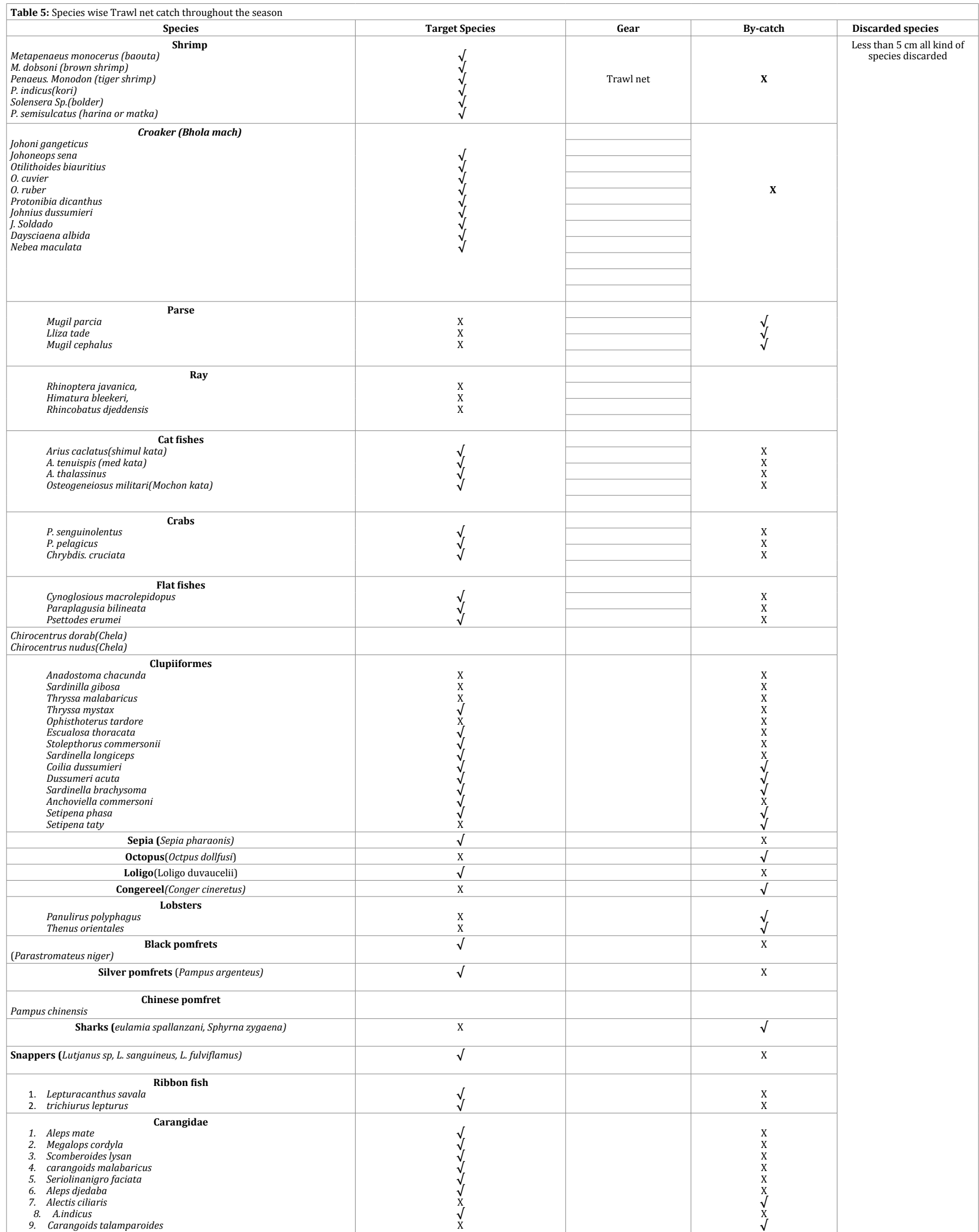


species of little commercial importance, which in most cases are dumped overboard either into the sea or in the landing sites. In West Bengal coast along with commercial fishing traditional fishing also creating a by catch problem. Shrimps being a major foreign exchange earner and in the race for valuable shrimp, a considerable by-catch is hauled up with it, by and large, ignored in many parts of the country. This by-catch, amounts to 90 per cent of the shrimp catch, discarded by trawlers and by other traditional fishing method in West Bengal is large biomass. A flow chart depicted below provides a comparative idea of by catch collection through specific crafts and gears during commercial and traditional fishing efforts.

Laval stages of crab, loligo, sepia, jelly fish ,cat fish, small bhola, shark, ray, ribbon fish , mullets, flat fish, were encountered in good quantity with the by catch and discard during the period of investigation (Figure 1, A \& B ), whereas, April and May are considered as banned period. During October and December, it was observed that matured female crabs carrying eggs and larvae in abdominal cavity were caught in good quantity in trawl nets in both the sampling centers. In Island areas of Sundarban of Namkhana region fishermen operate small mesh dragnets (bears similarity with mosquito nets) in order to catch acetes species (Jwala) throughout the year. But large quantity of larvae of lobster, different shrimps, flat fish, clupids etc. is being caught which are subsequently used as fishmeal.

\section{Results}

From the graphical representation and also from table. It is envisaged that total catch is more $(18301.9 \mathrm{~kg})$ in Digha region than that of Namkhana (17668.43 kg) coastal region. But when by-catch is compared it is more in Namkhana (5457.4 kg) than Digha (4923.43 kg). Again the discard, compared, it is more in Digha (1073.57 kg) than Namkhana (868.57 kg). When the said values are plotted in a graph considering the month wise catch, by-catch and discard amount from October to June, in both the cases, total catch showed highest peak in January. Then there is a decline in April and May as the two months are considered as the period of bann in capture fisheries in east coast of India. Again the said three criteria showed an increasing trend after May. When a correlation value, in accordance with the months, was compared, the values are significant at the level $(P>0.01)$ in terms of catch of the two regions (Figure 6).

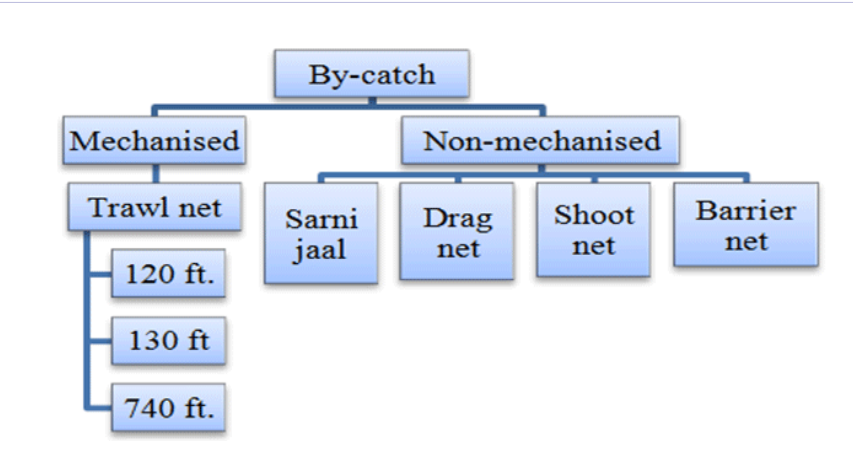

Figure 3: By catch collection through mechanized and different non mechanized indigenous gears

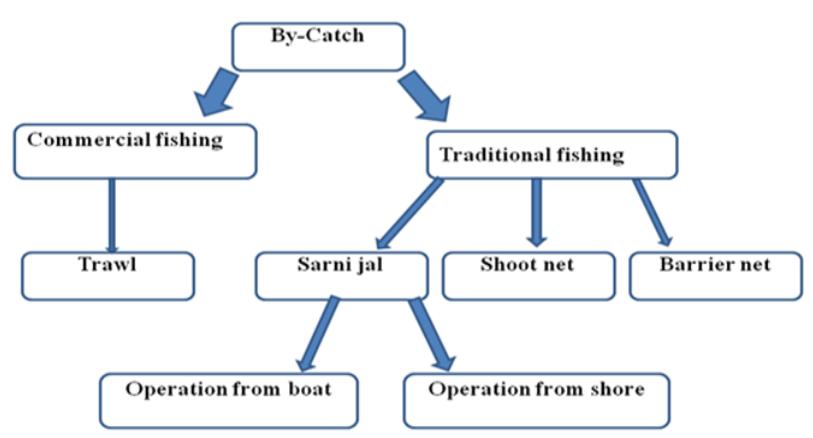

Figure 4: Flow chart indicating gears used during both traditional and commercial fishing

$$
\text { nvg catch } \quad \text { Avg discarded }
$$

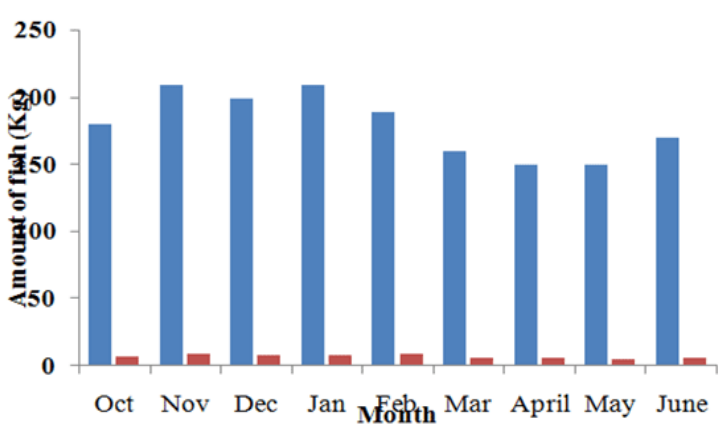

Figure 5:Relation between average fish catch and average discard per month through sarni jal
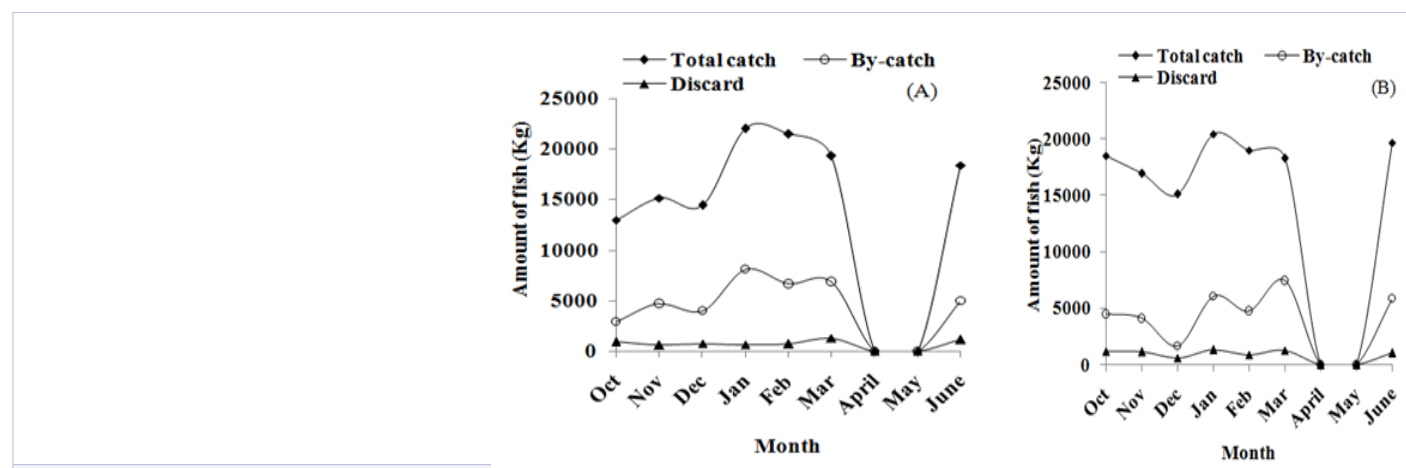

Figure 6: Month wise catch by trawl net in Namkhana (A) and Digha (B) region 
From the graphical presentation and also from (Table 2 - 5), it is envisaged that total catch is more $(42703 \mathrm{~kg}$ ) in Digha region than that of Namkhana (41226.33 kg) coastal region. But when by-catch is compared it is more in Namkhana $(12734 \mathrm{~kg})$ than Digha (11488 kg). Again when the discard is compared it is more in Digha (2505 kg) than Namkhana (2026.67 kg). When the said values are plotted in a graph to show the peak season of the catch, by-catch and discard values, it is observed in both the cases, the values reaches its peak (peak-2) during summer while the lowest values are observed during rainy season (peak-3) (Figure 7).

Bar diagram (figure 8) to show species wise by-catch indicating both higher and lower values in terms of different groups. When the values of the two regions were compared the, (G1) was found to be highest in Namkhana while (G2) was highest in Digha. Group 3 (G3) is markedly higher in Namkhana, when (G4) is almost comparable in the two regions. Again marked difference in by-catch was observed when (G5, G6 and G7) were compared.

(Table 2 -5), indicates an almost comparable value in regard to Group 8 (G8). Again marked difference in by-catch amount was observed in between (G9, G10). Though (G11) is almost comparable while there is a marked difference in the catch of two regions as indicated in the table. When the by-catch of species belongs different groups of the two regions were compared the correlation coefficient indicated a significant value $(P>0.01)$ as in (figure 8).
To find out the efficiency of two gears, in operation, in both the regions, a comparison was made by applying correlation but no significant values were obtained. This might be due to difference in catch composition and of targeted species of the individual gear (Figure 9).

When the group wise by-catch values were plotted in a graph in accordance with the month of catch by trawl net, (G1) registered an increasing trend from October onwards and reaches its highest peak in January, thereafter, from February onwards it declined sharply. Among the other groups, (G6) only showed an increasing trend during January and otherwise showed a overall comparable values with other groups and or species in the Namkhana region.

When the by-catch values of the Digha region are compared, (G1) again showed an increasing trend during October and January with a sudden decline in December. For the other three months (February to June) the values were almost comparable followed by slight ups and downs. (G7) indicated a peak in the month of March while (G8) maintained an overall decreasing trend when compared to the catch values of other group in Digha region (G1 = Small bhola; G2= Clupidae group; G3 = Cat fish; G4 = Flat fish; G5 = Small crab; G6 = Ribbon fish; G7 = Carangaids; G8 = Small pomfret; G9 = Sharks; G10= Rays; G11 = Conger eel; G12 = Cephalopods) (Figure 8, 9).
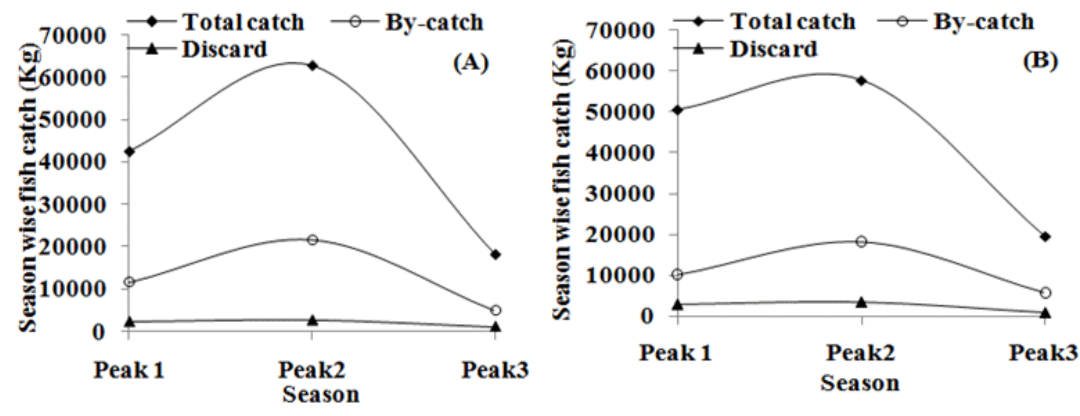

Figure 7: Season wis comparison of the total catch, by-catch and discard values of the two coastal zones Namkhana (A) and Digha (B) of West Bengal.

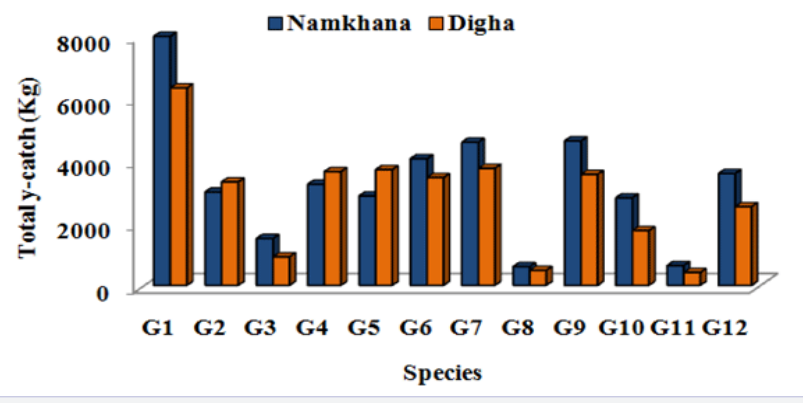

Figure 8: Species wise by-catch through trawl net in the Namkhana and Digha coastal zone

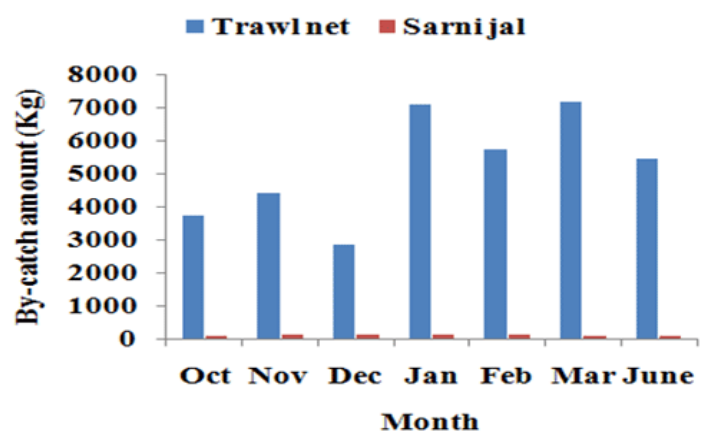

Figure 9: Relation between average fish catch and average discarded amount month wise operated sarni jal 


\section{Discussion}

The comparative data on target species, by catch and the discarded component through different gears are furnished through (Table 2-5). In targeting two species through Sarnijal, the by catch composition constituted of 9 (nine) major groups, out of which 6 (six) major groups are discarded. When the target species is one only (Penaeus monodon), through shoot net, all the fin and shell fishes caught are considered by catch and all are discarded. Targeting juvenile Mugil cephalus through barrier net all species, except $M$. cephalus, are considered by catch and discarded. During trawl net operation,14 (fourteen) species out of which 5 major groups, along with some species ( 2 or more) of clupiformes and Carangidae are considered by catch. Out which the species less than $5 \mathrm{~cm}$ are considered discard category.

The study indicate both the by catch and discard volume increases with the refinement and subsequent modification of the gears as also on its mesh size. Total catch, by catch and the discards of two coastal districts of West Bengal, India are presented in (Figure 6). In both the areas total catch amounts to on an average $20,000 \mathrm{~kg}$, which is somewhat more in Namkhana. In both the areas maximum catch were available during December to March, while April and May declared banned period. By catch were maximum (7000-8000 kg) during December to March. (Figure 4) also indicate, in both the areas, discards were negligible due to high market demand of the by catch product. By catch and discards are composed of larvae stages of crabs, loligo, Sepia, Jelly fish, catfish, small bhola, shark, ray, ribbon fish, mullets and flat fish in considerable amount. Matured female crabs carrying eggs and larvae in their abdominal cavity were encountered in good quantity.

Quantities of by catch through trawl nets in both the sampling site are more during October and December. In both the coastal region fisherman operates small meshed dragnet (Similar to mosquito net) to catch Acetes species (Jwala) throughout the year. The catch includes larvae of lobster, different shrimps, flat fish and clupeids in considerable amount, subsequently used as fish meal. A relationship of season wise catch of the two coastal points under study is depicted in (Figure 7). In (figure 10 and 11) group wise contribution of the by catch, both in terms of weight and percentage, are presented. Small bhola dominate the catch followed by flat fish, Ribbon fish, carangids, clupidae and other groups. In (Figure 12), contributions of individual group as by catch out of the total catch during the study period of nine months are present. Small bhola is the predominate group followed by other. In (Figure 13) percentage wise contribution of individual group out of the total is presented, while in (Figure 14) region wise by catch amount through trawl net is presented.

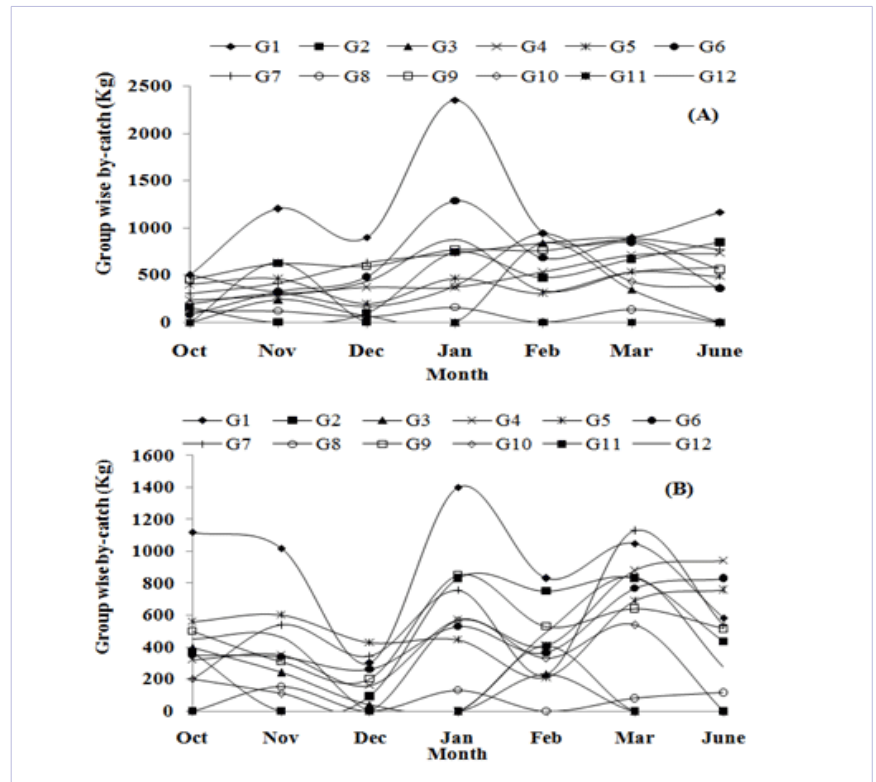

Figure 10: Group wise trawl net by-catch in Namkhana (A) and Digha (B) region
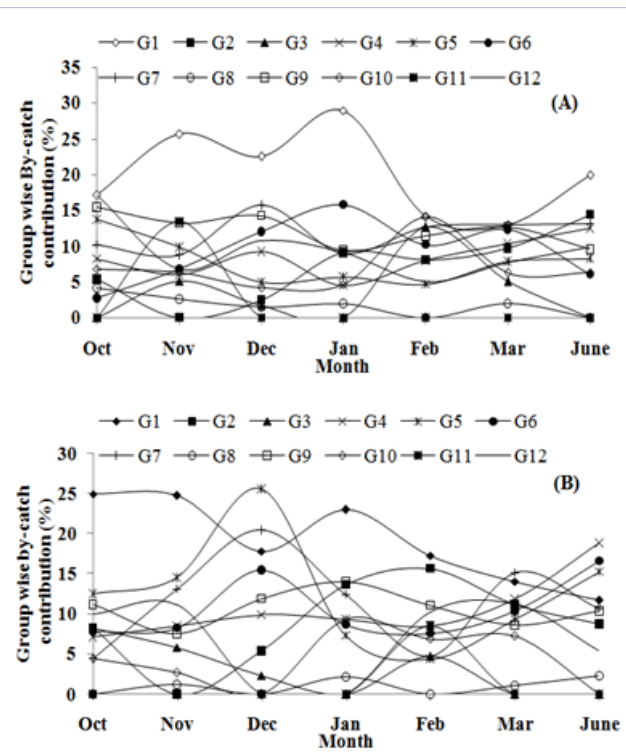

Figure 11: Group wise trawl net by-catch contribution (\%) in Namkhana (A) and Digha (B) region

(G1 = Small bhola; G2 = Clupidae group; G3 = Cat fish; G4 = Flat fish; G5 = Small crab; G6 = Ribbon fish; G7 = Carangaids; G8 = Small pomfret; G9 = Sharks; G10= Rays; G11 = Conger eel; G12 = Cephalopods 


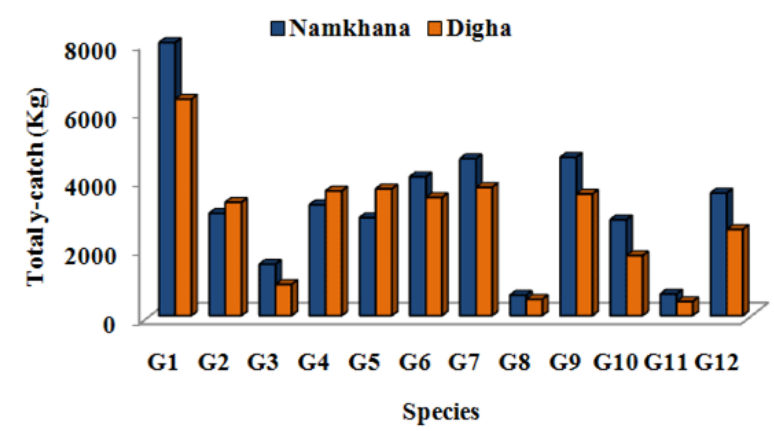

Figure 12: Group wise by-catch in the nine months

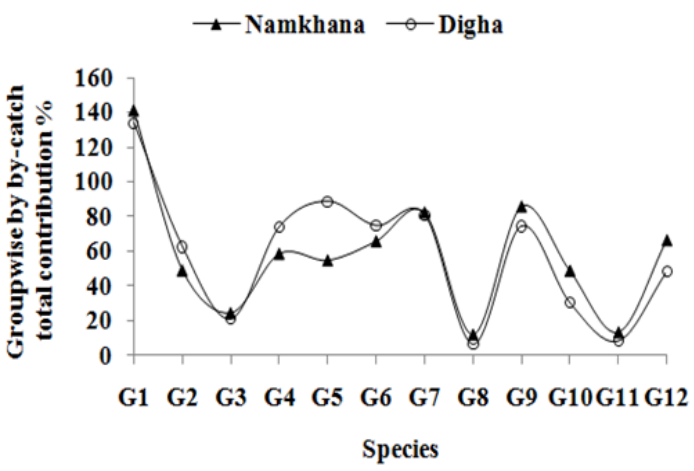

Figure 13: Group wise total by-catch in percent (\%) through trawl net

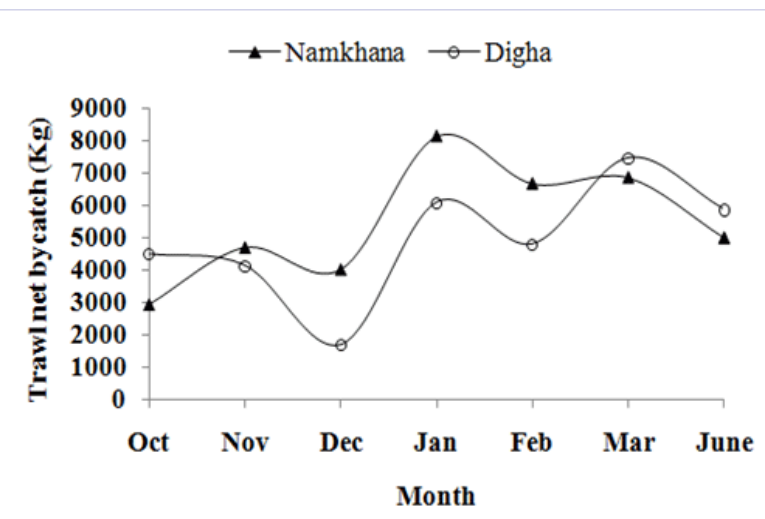

Figure 14: Region wise trawl net by catch

\section{Conclusion}

In India there no such consolidated scientific data as to the impact of huge loss of important species of fishes in the form of by catch and discards at its all stages. Information is scanty also on the quantity and quality of unintentional catch as well as its impact on biology and marine ecosystem. Available data indicates a huge volume of important fishes (both fin and shell fish) are lost throughout the years except the period of ban. This includes not only large fishes but also the smaller ones and gravid females with eggs in their abdomen. A study conducted in early 1990s showed that the bulk of marine landings in all of its maritime states consisted of juvenile fish (Luther G, et. al., 1993). due to the use of extremely small cod-end mesh size as low as $8-10 \mathrm{~mm}-$ only one-fourth of the $35 \mathrm{~mm}$ size that is legally required (Biju Kumar A, et.al., 2006 ; Bhathal B. ,2005).

Given that such a fishery cannot be considered managed and the entire catch of the Indian bottom trawl fleet is considered by catch. Though a considerable amount of by catch fetches a good market value still there is an urgent need to control such illegal fishing, particularly through trawl net to save the unique component of marine ecosystem. The first step, in this regard, may be towards determination of the scale to assess the magnitude of the problem. Fishing industry leaders are now increasingly realizing the need to reduce by catch and discards. Proven solutions for by catch reduction such as location and region specific modification of fishing gears may be explored to reduce the loss. The magnitude of the loss indicate immediate involvement of world bodies in the field of conservation biology and ecosystem to formulate devices for putting a check on such a negative consequences on marine ecosystem (Kumar, B, 2006).

\section{References}

1. Bhathal B. Historical reconstruction of Indian marine fisheries catches, 1950 -2000, as a basis for testing the Marine Trophic Index. Fisheries Centre Research Reports. Fisheries Centre, University of British Columbia. 2005;13(5).

2. BASU NC, PAKRASI BB. Brackish water fish and prawn seed potentialities of Bakkhali area in tower Sunderbans, West Bengal. Journal of the Inland Fisheries Society of India. 1979;2:40-48.

3. Biju Kumar A, Deepthi GR. Trawling and by-catch: implications on marine ecosystem. Current Science. 2006;90(7): 922-931.

4. Devaraj M, Vivekanandan E. Marine capture fisheries of India: Challenges and opportunities. Current Science.1999;76 (3):314-332.

5. Kelleher K. Discards in the world's marine fisheries - an update. FAO Fisheries technical paper 470, Food and Agriculture Organization of the United Nations, Rome. 2015.

6. Fishing gear type. Technology fact sheet in fisheries and aquaculture topics (internet). 2011.

7. Luther G, AppanaSastry Y. Occurrence of spawners, juveniles and young fish in relation to the fishery seasons of some major fishery resources of India-a preliminary study. Marine Fisheries Information Service, Technical and Extension Series. 1993;122:1-8.

8. Pauly D, Christensen V, Guenette S, Pitcher TJ, Sumaila UR, et al. Towards sustainability in world fisheries. Nature. 2002;418(6898):689-695. doi:10.1038/nature01017

9. Pauly D, Christensen V, Dalsgaard J, Froese R, Torres FJ. Fishing Down Marine Food Webs. Science. 1998;279(5352):860 - 863. 